\title{
Editorial: The Wisdom of Age
}

'Philosophy' means love of wisdom. So is philosophy primarily and rightly the province of those traditionally assumed to be wise, namely the old? A ristotle might have subscribed to some view of this sort. F or him only those well on the way to middle age had the experience necessary to discourse sensibly on moral and political matters. Plato too, one suspects, would have agreed with something of the sort, al beit for different reasons. I $\mathrm{N}$ The R epublic education in wisdom just took an awful long time.

So what of the younger thinker who, in a burst of revolutionary fervour, changes the course of the subject, figures such as D escartes, N ietzsche, Russell, Wittgenstein and Ayer, down to the Young Turks of recent decades? Over recent centuries young philosophers have contributed much to the subject, particularly as philosophy itself has become infatuated with mathematics and science. Could there be a connection? And did any of the young men of philosophy increase in wisdom as they got older? $\mathrm{N}$ ietzsche? R ussell? Wittgenstein? Ayer?

A cynic might suggest that in the past the very old were thought wise because there were so few of them. But now that the whole population is ageing, can we expect a renaissance of wisdom and a flowering of philosophy? And if not, is it because in the modern world the old characteristically ape the young? T.S. Eliot hinted at a more mundane reason when he asked not to be told

Of the Wisdom of old men, but rather of their folly,

T heir fear of fear and frenzy, their fear of possession

Of belonging to another, or to others, or to G od.

Is this harsh observation of the narrowness of age as close to the truth as the conventional piety? 